\title{
EL LÍDER Y LA FELICIDAD
}

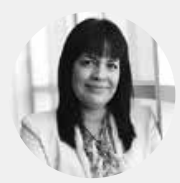

\author{
SILVIA J. GARCÍA \\ - Profesora de Comunicación para el Cambio \\ Dirección de Administración y Recursos Humanos \\ Facultad de Negocios, UPC
}

Nuestro comportamiento hacia los demás es a menudo un reflejo de cómo nos tratamos a nosotros mismos.

\section{(Tal Ben-Shahar)}

Para afrontar con éxito este mundo competitivo y obtener buenos resultados, las organizaciones necesitan mejorar el desempeño de sus directivos, no sólo en temas de gestión de recursos, sino también, en las de gestión de personas; $y$ para ello, las competencias personales juegan un rol muy relevante. Actualmente ya no hablamos sólo de jefes o gerentes, sino de líderes, de personas capaces de trasmitir confianza y credibilidad y que a la vez logran que los demás estén motivados y promueven una visión compartida influyendo de manera positiva en cada miembro de su equipo de trabajo y en toda la organización.

Es posible que al describirlo dudemos si podemos encontrar para nuestras organizaciones líderes con todas estas características y habilidades; o si nosotros, como jefes, poseemos todos esos atributos. La buena noticia es que las competencias personales sí se pueden desarrollar. Es por eso que tenemos al alcance programas de capacitación, procesos de coaching y actividades para fortalecer las habilidades directivas. Las empresas invierten en capacitar a sus jefes porque están seguros que mejorar estas competencias tendrá un impacto positivo no sólo para la organización, sino también, en otros, en el entorno de trabajo (e.g., reportes directos, gerentes, colegas, clientes, etc.).

Para lo anterior surgió un nuevo enfoque que combina la gestión y el liderazgo para hacer frente a las necesidades de desarrollo de los colaboradores y las organizaciones. Preferentemente se habla hoy del líder transformacional, un líder que influye por convicción, un modelo a seguir, ético y con valores. Sin embargo, una persona no puede ejercer influencia positiva en otros, si primero no ha desarrollado su propio liderazgo personal, que implica ser consiente de quién es, conocer sus fortalezas y limitaciones y a la vez tiene que ver con sentirse feliz y motivado, tanto en su vida personal, como en su vida profesional.

Entonces, reflexionemos unos minutos y preguntémonos si somos o no líderes felices.

De acuerdo al concepto brindado por Michael Argyle, en su libro La psicología de la felicidad, publicado en 1992, la felicidad es "el sentimiento que se deriva de tener emociones positivas o de estar satisfechos con nuestras

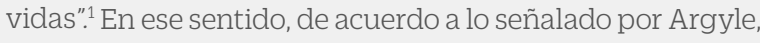

la felicidad tiene dos ejes: el de las emociones y el de la satisfacción con nuestra propia vida. Tiene que ver con cómo me siento y qué tan satisfecho me siento en relación con mi trabajo y con mi desarrollo profesional; pero no sólo en el ámbito laboral, sino también en lo personal: en relación conmigo mismo, mi familia, las personas que amo y las cosas que disfruto hacer.

No necesariamente sentirse satisfecho va de la mano con emociones positivas, relacionadas a la felicidad. Una persona que tiene su empresa y está obteniendo los resultados que esperaba puede sentirse satisfecho con los resultados, pero puede sentir también emociones negativas, como aburrimiento o cansancio (porque está estresado por tantas horas de trabajo) o culpa (porque siente que le ha dedicado muy poco tiempo a su familia en los últimos meses).

En ese caso, el reto está en ser consciente de las emociones que vivimos y analizar que detrás de cada emoción negativa se encuentra el miedo. Miedo a no obtener el resultado esperado; miedo a no ser capaz; miedo a ser juzgado; miedo a no ser aceptado, por mi jefe, por mi equipo de trabajo, por mi pareja, por mis hijos,... miedo. Al reconocer nuestras emociones, sin embargo, entonces somos capaces de influir en nuestros pensamientos y por la tanto en la manera de cómo nos sentimos frente a una situación determinada. Esto nos da el poder de elección. Yo elijo mis pensamientos, mis emociones y decido cómo actuar frente a las circunstancias. Tengamos en cuenta que lo que pensamos y sentimos nos hace reaccionar de una determinada manera, negativa o positiva, frente a nosotros mismos y frente a los demás.

Un líder es aquél que logra superarse a sí mismo y ser mejor persona cada día; y este es un entrenamiento de largo plazo. Cada día es un reto para convertirnos en mejores seres humanos. Practiquemos con nosotros mismos: con autoestima, automotivación y respeto. Así construiremos una percepción positiva de nosotros mismos y de nuestro entorno; mejorarán nuestras relaciones interpersonales; y miraremos a los demás de una manera distinta con amor y gratitud. En cada momento podemos decidir ser felices, disfrutar cada pequeño logro y aprender de nosotros mismos y de los demás. Y aunque la siguiente frase suene repetitiva la felicidad no es una meta, la felicidad es el camino. Permitámonos vivirla.

1. Citado por David Fischman en su libro, La alta rentabilidad de la felicidad (2017). 